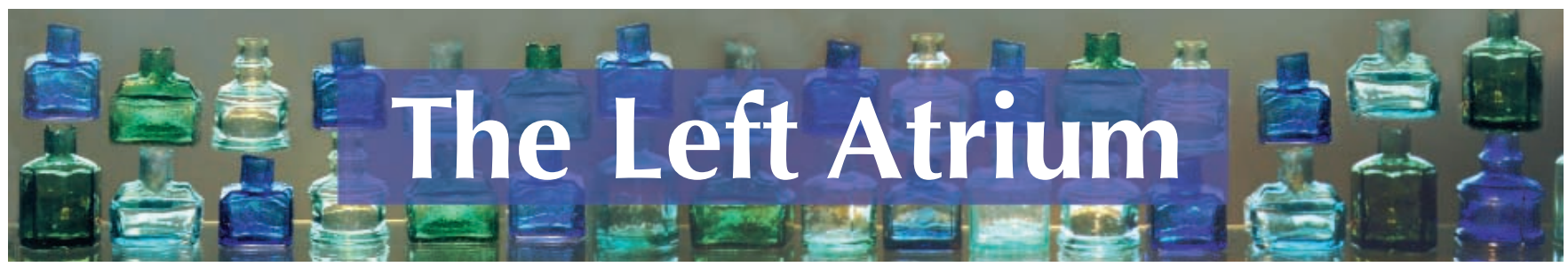

\section{The Olivieri story, take three}

The drug trial

Miriam Shuchman

Toronto: Random House; 2005

451 pp \$34.95 ISBN 0-679-31084-3

$\mathrm{T}$ his aptly titled account by journalist and psychiatrist Miriam Shuchman describes not only the clinical trials of deferiprone, a second-line therapy for thalassemia major, but also the very public trials of hematologist and clinical researcher Nancy Olivieri. Judging by a communication this journal received from Dr. Olivieri, which provides in seven and a half pages an "incomplete list of inaccuracies and omissions by Shuchman" that Olivieri considers to be "defamatory of [her] scientific integrity, honesty, motives, character and reputation," the public trial is not yet over. Nor is the scientific controversy. Deferiprone is approved for use in many countries in Europe and Asia, but not in Canada or the United States. Olivieri has been as steadfast in her conclusion that the drug is dangerous and ineffective as others have been in disputing her findings. But, for many spectators, the scientific nuances have been lost against a Davidand-Goliath drama that made it to the front pages of national newspapers and the covers of glossy magazines and even became the stuff of popular fiction.

Many Canadians are familiar with Olivieri's confrontation with Apotex, the pharmaceutical firm that funded some of her investigations into "L1," the drug that offered thalassemia patients an alternative to the standard - and onerous - treatment with Desferal to manage iron overload. Olivieri's difficulties entered the media spotlight with her publication of findings that she and her coauthors believed showed that deferiprone therapy had dangerous side-effects. The subsequent scientific controversy hinged on the interpretation of liver biopsy specimens from several patients and on the authors' selection of specimens in their analysis.

Olivieri and one of her colleagues, Gideon Koren, had signed a contract with Apotex that precluded the publication of their findings for up to 3 years unless the company gave consent. Apotex refused to grant permission to publish and threatened legal action in the event of a confidentiality breach. Olivieri forged ahead with publication despite this threat, and instantly became celebrated as a courageous whistle-blower in the face of corporate greed. Also appearing in the arena were the Hospital for Sick Children and the University of Toronto, whose failure to fully support Olivieri's dispute with Apotex became the scandal of the academic community and a rallying point for professional allies dubbed "The Gang of Four," who acted as advisors, friends, media spokespersons and amateur private investigators.

The series of events that led to the conflict between Olivieri and Apotex and between Olivieri and her employers, the $\mathrm{U}$ of $\mathrm{T}$ and Sick Kids, has been the subject of two previous investigations. First to tackle l'affaire Olivieri was the $\mathrm{U}$ of $\mathrm{T}$. The university commissioned a one-person inquiry by Dr. Arnold Naimark, a distinguished scientist at the University of Manitoba - which, like the $\mathrm{U}$ of $\mathrm{T}$, had received substantial grants from Apotex. Olivieri and her colleagues refused to cooperate with Naimark, claiming he was biased. His report, thus, necessarily tells only part of the story. The Canadian Association of University Teachers, a faculty union, then launched its own investigation under the leadership of 3 equally distinguished academics, Jon Thompson, $\mathrm{Pa}-$ tricia Baird and Jocelyn Downie. But key players declined to participate in their investigation; thus this second version of events is also incomplete.

Shuchman's book, which took her 5 years to research and write, came after legal settlements had been brokered. Shuchman was able to interview most players in the conflict and was given access to written documentation. Shuchman's named sources (not everyone was willing to speak on the record) are so numerous that readers will likely make frequent reference to an appendix of key players to keep them all straight. Shuchman's account is a sometime laborious blow-by-blow of events. As she points out, stories that acquire the ring of truth in the media are usually simple and compelling; her version of events is convoluted and involves many shades of grey.

She begins with a review of the background to the discovery and initial investigation of desferiprone and traces the drug's progress through different laboratories and manufacturing interests. Shuchman also portrays some of Olivieri's patients and their families, whose varying perspectives are represented here. In the wealth of detail about Olivieri's battles with Apotex, the U of $\mathrm{T}$ and Sick Kids, and in her detailed documentation of sources in a lengthy appendix, Shuchman appears to present evidence not only for a factual sequence of events, but also for the personal and professional motivations of Olivieri and others. But this, clearly, will always be disputatious ground; however confident the reader may be in Shuchman's journalistic diligence, human motivations always leave room for interpretation. 
Whether the reader accepts Shuchman's claim that Olivieri's doubts about desferiprone has created an unnecessary setback to thalassemia treatment in this country, they will revise any comfortable notions about the quiet, altruistic world of clinical research. Perhaps this intricate account is most useful as a lesson in the complexities of industry partnerships in academic research; Shuchman writes, "[t]he debacle of Nancy Olivieri and the pill to save thalassemia patients revealed every crack in the system." More happily, in the wake of the biggest scandal in the previously quiet annals of Canadian science, new guidelines emerged for industry sponsorship of research, the publication of results and the protection of scientists' intellectual property rights. Nonetheless, what thalassemia patients will make of this account of the unglamourous underbelly of clinical research is painful to contemplate; it is they, more than anyone, who need relief from ambiguity, uncertainty and scientific dispute.

\section{John Hoey \\ Anne Marie Todkill \\ CMAF}

\section{Room for a view}

\section{Witness to a birth}

$\mathrm{P}$ alimar is a sleepy hamlet tucked deep in the hinterland of westcoastal India. A single mud track leads to this place; a once-a-day bus, and an occasional radio, provide the only connection with the outside world. This is where I found myself, at a whim, in 1971 when I was forced by circum-

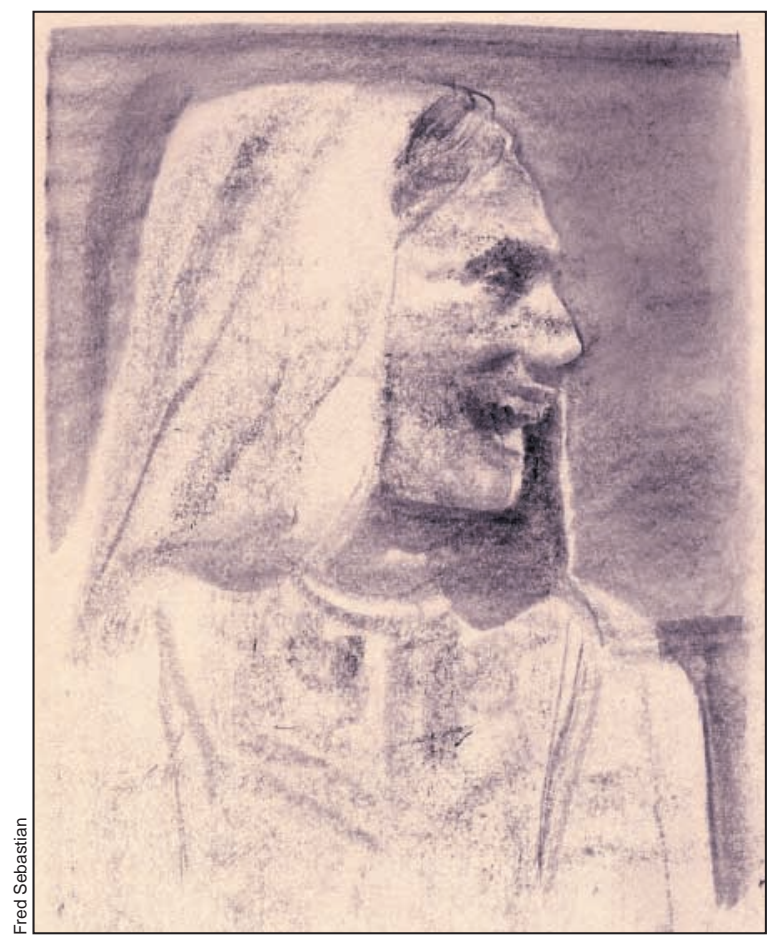

stance to interrupt my second year of medical studies. A friend, a drawing master in the village school, provided spartan lodging. Board was at the simple tile-roofed house of the local headmaster a few miles off. The villagers treated me with a deference no doubt inspired by the fact that I was a medic, even if a half-baked one.

I whiled away the time, taking treks into the shrub jungles that nestled Palimar. The headmaster's wife, a motherly lady, plied me with endless mounds of fluffy rice and spicy soup. At supper's end, the headmaster would call out, Annadurai ide balle, eela Gowri Thomas, eela ba Come on over Annadurai, you too, Gowri Thomas - and two very meanlooking cats would respond. Named after politicians of the day, they would polish off what little remained as scraps on the banana-leaf plates.

My interlude from study was one day interrupted rudely by a gaggle of agitated voices and some frantic knocks.

"Headmaster's daughter is having labour pains, and he wants you quickly."

Now this was calamity compounded. I neither had the knowledge nor the wherewithal to attend obstetric situations. My aversion to blood and emergencies had already made me a misfit at the medical college. Gulping hard, I hurried along with the group, walking in the dark with a lantern in one hand and a stick in the other. The latter was a must in those parts. Doom beckoned the unwary who might get bitten by a cobra, but woe also befell anyone naive enough to club that cobra to death. The rural folk revered snakes, and any snake-killer was enjoined to feed a few Brahmans and arrange for a serpent funeral as atonement.

Soon we were in the headmaster's dimly lit house. In the tiny anteroom, writhing on a straw mat on the floor, lay the labouring woman. She was barely seventeen and looked very frightened. She winced with pain every time a contraction ripped through her fragile frame. I saw in the glow of the kerosene lamp her worried father and handwringing mother. Beside them was an- 